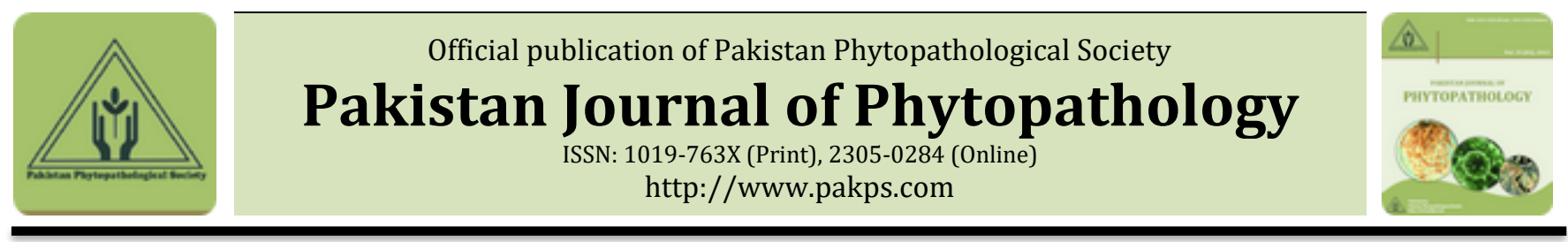

\title{
SIGNIFICANCE OF RECENT DISCOVERIES IN STRIPE RUST MANAGEMENT
}

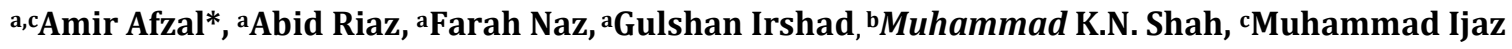 \\ a Department of Plant Pathology, PMAS Arid Agriculture University, Rawalpindi, Pakistan. \\ ${ }^{b}$ Department of Plant Breeding \& Genetics, PMAS Arid Agriculture University, Rawalpindi, Pakistan. \\ ${ }^{c}$ Barani Agricultural Research Institute, Chakwal, Pakistan.
}

\section{A B S T R A C T}

Stripe rust in wheat is the most problematic disease damaging the produce severely in wheat growing regions. In this paper findings in recent past related to yellow rust with reference to their application in the management of disease have been debated. In this regard various aspects of breeding for resistance were focused. Pathogen has adopted under the changed climatic scenario brings and disease is observed in the regions where it did not exist earlier. Rising temperatures has increased the irregularity and concentration of precipitation, causing the spread and severity of rust diseases. NB-LRR proteins are expected to play a substantial part in advanced agriculture where yield is the primary goal for screening. Biotechnology has revolutionized in biological sciences including Plant Pathology. Experts are studying the biochemical nature and the signals involved in, a plant's responses to pathogen attack and development of disease. Plant resistance genes are being engineered into plants to defend them from plant diseases.

Keywords: Wheat, Stripe rust, Puccinia striiformis f. sp. tritici, PST, DNA Markers.

\section{INTRODUCTION}

Rusts cause severe damage to wheat contributing to food insecurity (Todorovska et al., 2009). Among three rust diseases, stripe rust is most aggressive (Wellings, 2011). Stripe rust is recognized by its significant, yelloworange spore pustules organized in stripes along the leaf blades contrary to the small sized, cinnamon brown pustules of leaf (brown) rust (Figure 1).

Stripe rust of wheat, acknowledged in many parts of the world as 'yellow rust' for its yellow-orange urediniospores. Disease is caused by Puccinia striiformis f. sp. tritici (Pst) (Chen et al., 2013). Stripe rust is the alarm for wheat production in the world and has been increasingly destructive in many countries including Pakistan (Solh et al 2012). The reduced yield due to this disease may lead to severe economic losses

Submitted: January 30, 2018

Revised: June 17, 2018

Accepted for Publication: December 24, 2018

* Corresponding Author:

Email: rajaamirafzal@gmail,com

(C) 2017 Pak. J. Phytopathol. All rights reserved.
(Ali et al., 2017). Thus, control of the disease is crucial to ensure food security. Increased incidence of certain diseases due to the invasion of new pathogens or its new strains/pathotypes, the change in host range of an existing pathogen and/or the acquisition of increased fitness by the pathogen is attributed to change in climate (Agrios, 2005). The new races of yellow rust have adapted to warmer temperatures leading extension in area prone to disease (Milus et al. 2009; Afzal et al., 2017). Epidemics have occurred damaging severe recently in Middle East, Central Asia, Western Asia, Eastern and Northern Africa and China, in the regions which were considered inapt for disease previously (Hovmøller et al., 2010; 2011).

Some recent discoveries: The life cycle of PST remained unknown till Jin et al., 2010 demonstrated the erotic phase of organism causing stripe rust in wheat. Discovery influenced our acquaintance of the genetics of pathogen and led to the evolution of better approaches for stripe rust management. Revelation of comprehensive life history of pathogen led to address the dilemma in new mode. Investigation was carried to 
discover the phenomenon of current global epidemics of wheat yellow rust. Research was conducted to discover the structure of population associated with epidemic. The findings of the work indicated signatures of both spatial structuring as well as invasion for this disease (Ali et al., 2014). Population genetic analyses showed solid local diversity with strong signs of recombination in zones Himalaya and near-Himalaya whereas in other regions of the planet a major clonal population structure is dominant. Abundance of alternate host (Berberis spp.) in the regions propose the area as credible center of origin or in any case the nearer to its center of origin of PST (Bueno-Sancho et al., 2017). However, more investigation from east Asian to central Asia regions may generate valuable information.

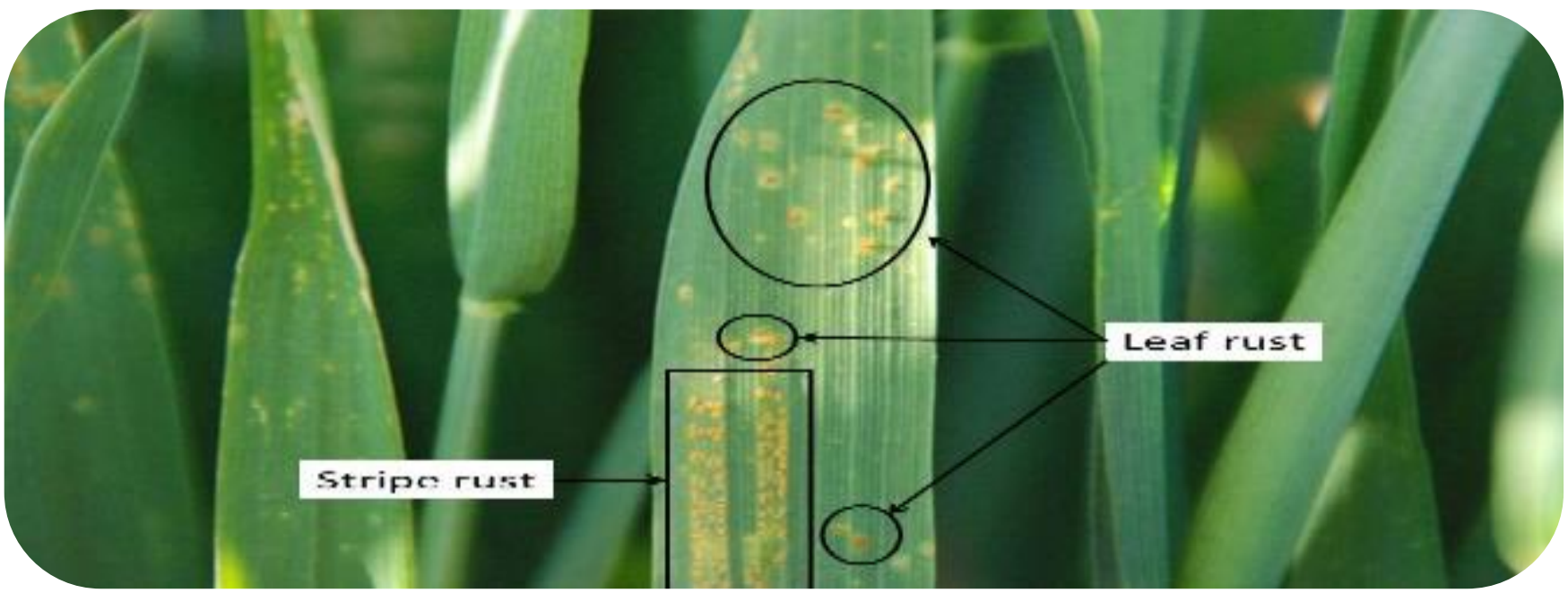

Figure 1. Distinction in stripe rust and Leaf rust.

Genetic diversity of the local population of PST was compared with the NW-European population, targeting the Khyber Pakhtoon Khawah (KPK), a region where yellow rust is endemic. Work conducted revealed 12 pathotypes designated in KPK (Bahri et al., 2011), with 3 already documented in Pakistan (Hakim et al., 2001) in the studied sample. The finding of work characterizes a main variance from the European condition, where only two to four pathotypes exist on an analogous local level.

27 different genotypes were described using 15 microsatellite markers. All the pathotypes branded in NW Europe show a single Simple Sequence Repeat genotype in the last 20 years, and pooling the Western Mediterranean population adds 5 supplementary SSR genotypes (Bahri et al., 2009). Postulation conducted revealed that few genes like Yr2, Yr6, Yr7, Yr9, Yr27 and YrSU, were found frequently in wheat genotypes under cultivation in Pakistan (Figure 2).

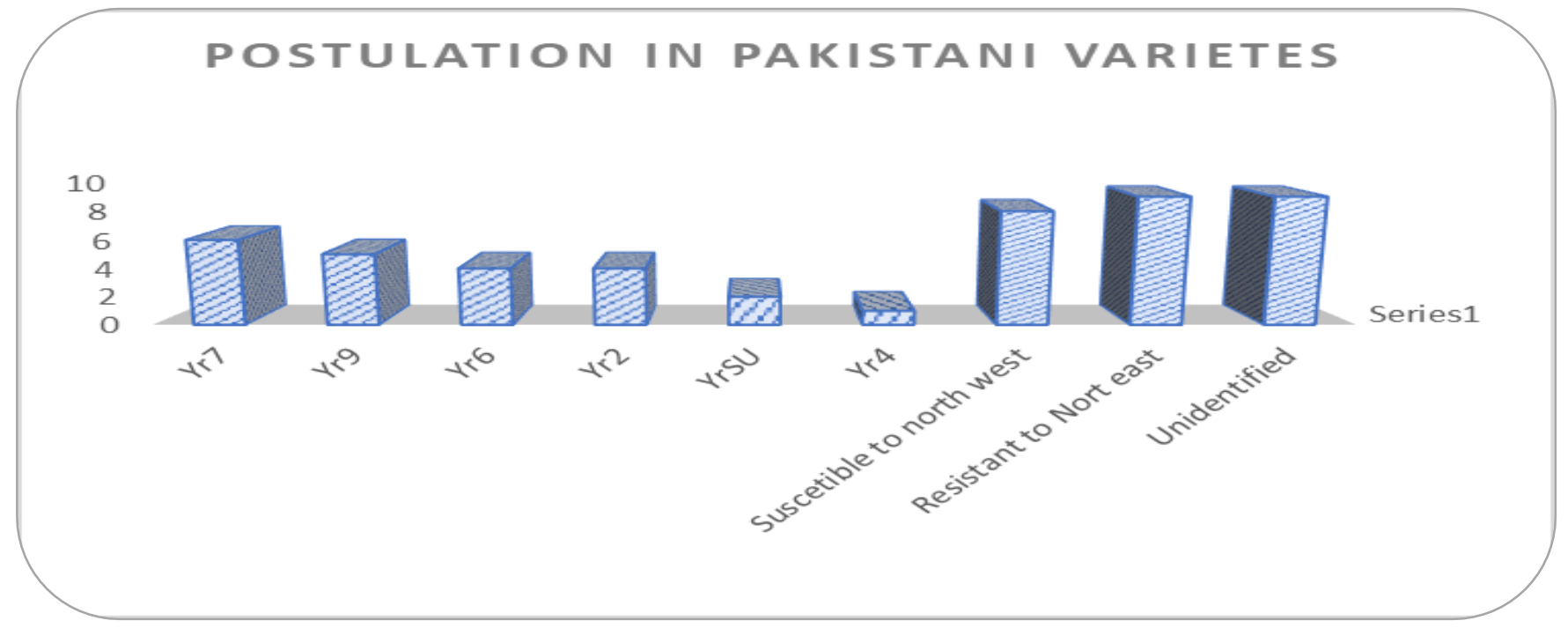

Figure 2. Gene postulation of Pakistani Cultivars (Bahri et al., 2011). 
Mago et al., 2011 enlisted several perfect markers for wheat rust resistance genes prevailing at present. Advances in biotechnology laid to the foundations for identification of pathogen in vivo (Steuernagel et al., 2016). Resistance controlled through major genes has not proved durable and led to arms race in host and pathogen. Consequently changed strategy and identification of sources of durable resistance to stripe rust is the target in wheat improvement programmes (Vazquez et al., 2015; Afzal et al., 2018). Combinations of major and minor resistance genes led to engineering more durable genotypes against rust (Chen, X. 2013; Hulbert and Pumphrey, 2014).

Identification of a novel class of NB-LRR genes where resistance involves the role of both genes is an vital innovative progress (Cesari et al., 2014; Zhai et al., 2014). Effectors are $\mathrm{R}$ proteins that distinguish fungal proteins, inside the plant cytoplasm even and activate a defense reaction that pauses reproduction in pathogen (Ellis et al., 2014; Steuernagel et al., 2016).

How these findings may be functional in management of dilemma: Researchers disclosed routes of migration, population structures, modes of reproduction and evolution outlines in work conducted in recent past (Ali $e t$ al. ,2014a, b; Hubbard et al., 2015; Hovmøller et al., 2016; Thach et al., 2016; Walter et al., 2016). Agricultural scientists are working to maintain improve crop yields with healthy crop, and reduced practice of pesticide through the application of Plant biotechnology. Biotechnology boosted the method of recognizing plant pathogens with greater precision, a requirement for control of the diseases. Plant genes and gene products that interact with pathogens have been recognized and either inserted into plants or used as specific molecular markers to improve disease resistance through plant breeding. Biotechnology influences almost all features of plant pathology. Biotechnology is applied to improve the effectiveness of rust resistance breeding through the exploitation of DNA markers in gene pyramiding, confirmation of the occurrence of genes and purity of released cultivars. This requires DNA markers that are precise and applicable across wide ranges. One of the final purposes of application of biotechnology in agriculture is to feed growing population in the world (Fermin-Munoz, 2000).

The finding of the work conducted by Ali et al. 2018 emphasizes the lack of probability of appearance of new races with potential to cause severe epidemic, which needs more effort in population biology and surveillance activities of pathogens on worldwide food crops, and assessments of disease vulnerability of host varieties before their distribution at higher levels.

Advances in biotechnology as well as statistics facilitated the deploying resistance gene combinations more and more that bring highly effective marker tagging systems (Burdon et al., 2014). Briefly, we may be able to make true development in comprehending the molecular means that makes Pst such an effective pathogen. Such elementary progress will facilitate us to investigate and answer key biological queries enlisted as under.

$>$ How do R gene-recognized effectors function?

$>$ Mechanisms involved in Pst evolution at nucleotide resolution

$>$ Role of haploid genome to the development of new Pst virulence pattern

NB-LRR proteins identifies Pathogen strain (effector), convert $\mathrm{R}$ protein from the latent to dynamic condition and signal to the machinery of host defense response and may deliver a race nonspecific resistance along with race specific resistance (Marone et al., 2013; Hurni et al., 2014). Precise markers for each $R$ gene will confirm elimination of the speculation and accelerate the genotype postulation by genetic analysis and screening against various pathotypes (Ellis et al., 2014). However, only DNA markers are not be adequate in some situations and the analysis of observable characteristics of an individual resulting from the interaction of its genotype with the environment is still be essential there.

\section{CONCLUSION}

This review presents the impact of fresh data regarding the climatic conditions under which disease flourishes the most, fluctuations in virulence pattern of pathogen and population structure, and dynamics of the pathogen around the world. Policy for management of stripe rust has been amended with revelation of comprehensive life cycle for $P$. striiformis $\mathrm{f}$. sp. tritici. Significant increase in adaptation to warmer temperatures has been noticed in new races of yellow rust subsequently new regions have become prone to disease. Further research work is needed to answer whether the current global epidemics of wheat yellow rust was because of propagation of genotypes of limited clonal lineage(s) or populations of different races. Regulatory protein polymorphisms have the perspective to make available general pathogen resistance in near future. Application of biotechnology in the discipline of Plant Pathology has brought revolution. 
Experts are studying the biochemical nature, and the indicators, a plant's response to pathogen invasion and disease development. Plant resistance genes and the resistant genes are being recognized and incorporated into crop plants to defend plant against diseases.

\section{REFERENCES}

Afzal, A., A. Riaz, and R. M. Rana 2017. Screening and pedigree based genetic diversity analysis of wheat advanced lines against stripe rust under changing climatic scenario. International Conference on Tackling Climate Change through Plant Breeding: 53-54.

Afzal, A., A. Riaz, F. Naz., G. Irshad and R. M. Rana. 2018. Detection of durable resistance against stripe rust and estimating genetic diversity in wheat through pedigree analysis of candidate wheat lines. International Journal of Biosciences 12: 3: 24-35.

Agrios, G. N. 2005. Introduction to plant pathology. Elsevier Academic Press Publication.

Ali, S., M. Leconte, H. Rahman, M. S. Saqib, P. Gladieux, J. Enjalbert and C. de Vallavieille-Pope. 2014. A high virulence and pathotype diversity of Puccinia striiformis f.sp. tritici at its centre of diversity, the Himalayan region of Pakistan. European Journal of Plant Pathology, 140: 275-290.

Ali, S., P. Gladieux, M. Leconte, A. Gautier, A. F. Justesen, M. S. Hovmøller, J. Enjalbert and C. de VallavieillePope. 2014. Origin, Migration routes and worldwide population genetic structure of the wheat yellow rust pathogen Puccinia striiformis f.sp. tritici. PLoS Pathogens, 10: e1003903.

Ali, S., Y. Liu, M. Ishaq, T. Shah, A. Ilyas and I. U. Din. 2017. Climate change and its impact on the yield of major food crops: Evidence from Pakistan. Foods, 6: 39.

Bahri, B., M. Leconte, C. de Vallavieille-Pope and J. Enjalbert. 2009. Isolation of ten microsatellite loci in an EST library of the phytopathogenic fungus Puccinia striiformis f.sp. tritici. Conservation Genetics, 10: 1425-1428.

Bahri, B., S. J. A. Shah, S. Hussain, M. Leconte, J. Enjalbert and C. de Vallavieille-Pope. 2011. Genetic diversity of the wheat yellow rust population in Pakistan and its relationship with host resistance. Plant Pathology, 60: 649-660.

Bueno-Sancho, V., A. Persoons, A. Hubbard, L. E. CabreraQuio, C. M. Lewis, P. Corredor-Moreno, D. C. E. Bunting, S. Ali, S. Chng, D. P. Hodson, R. Madariaga
Burrows, R. Bryson, J. Thomas, S. Holdgate and D. G. O. Saunders. 2017. Pathogenomic analysis of wheat yellow rust lineages detects seasonal variation and host specificity. Genome Biology and Evolution, 9: 3282-3296.

Burdon, J. J., L. G. Barrett, G. Rebetzke and P. H. Thrall. 2014. Guiding deployment of resistance in cereals using evolutionary principles. Evolutionary Applications, 7: 609-624.

Césari, S., H. Kanzaki, T. Fujiwara, M. Bernoux, V. Chalvon, Y. Kawano, K. Shimamoto, P. Dodds, R. Terauchi and T. Kroj. 2014. The NB-LRR proteins RGA4 and RGA5 interact functionally and physically to confer disease resistance. The EMBO Journal, 33: 1941-1959.

Chen, X. 2013. Review Article: High-Temperature AdultPlant Resistance, Key for Sustainable Control of Stripe Rust. American Journal of Plant Sciences, 04: 608-627.

Ellis, J. G., E. S. Lagudah, W. Spielmeyer and P. N. Dodds. 2014. The past, present and future of breeding rust resistant wheat. Frontiers in Plant Science, 5.

Fermin-Munoz, G. A., B. Meng, K. Ko and S. MazumdarLeighton. 2000. Biotechnology: A new era for plant pathology and plant protection. APSnet Feature Articles.

Hakim MS, Y. A., El-Naimi M, Maaz I. 2001. Wheat yellow rust pathotypes in Western Asia. in: Johnson $\mathrm{R}$, Y.A., Wellings C, Saidi A, Ketata H, (Ed.), Meeting the Challenge of Yellow Rust in Cereal Crops. Proceedings of the Regional Conference on Yellow Rust in the Central and West Asia and North Africa Region. International Center for Agricultural Research in the Dry Areas (ICARDA), pp. 55-61.

Hovmøller, M. S., C. K. Sørensen, S. Walter and A. F. Justesen. 2011. Diversity of Puccinia striiformison cereals and grasses. Annual Review of Phytopathology, 49: 197-217.

Hovmoller, M. S., S. Walter and A. F. Justesen. 2010. Escalating threat of wheat rusts. Science, 329: 369-369.

Hovmøller, M. S., S. Walter, R. A. Bayles, A. Hubbard, K. Flath, N. Sommerfeldt, M. Leconte, P. Czembor, J. Rodriguez-Algaba, T. Thach, J. G. Hansen, P. Lassen, A. F. Justesen, S. Ali and C. de VallavieillePope. 2015. Replacement of the European wheat yellow rust population by new races from the centre of diversity in the near-Himalayan region. 
Plant Pathology, 65: 402-411.

Hubbard, A., C. M. Lewis, K. Yoshida, R. H. RamirezGonzalez, C. de Vallavieille-Pope, J. Thomas, S. Kamoun, R. Bayles, C. Uauy and D. Saunders. 2015. Field pathogenomics reveals the emergence of a diverse wheat yellow rust population. Genome Biology, 16: 23.

Hulbert, S. and M. Pumphrey. 2014. A time for more booms and fewer busts? Unraveling cereal-rust Interactions. Molecular Plant-Microbe Interactions, 27: 207-214.

Hurni, S., S. Brunner, D. Stirnweis, G. Herren, D. Peditto, R. A. McIntosh and B. Keller. 2014. The powdery mildew resistance gene Pm8 derived from rye is suppressed by its wheat ortholog Pm3. The Plant Journal, 79: 904-913.

Jin, Y., L. J. Szabo and M. Carson. 2010. Century-old mystery of Puccinia striiformis life history solved with the identification of Berberis as an alternate host. Phytopathology, 100: 432-435.

Mago, R., G. Brown-Guedira, S. Dreisigacker, J. Breen, Y. Jin, R. Singh, R. Appels, E. Lagudah, J. Ellis and W. Spielmeyer. 2011. An accurate DNA marker assay for stem rust resistance gene $\mathrm{Sr} 2$ in wheat. Theoretical and Applied Genetics, 122: 735-744.

Marone, D., M. Russo, G. Laidò, A. De Leonardis and A. Mastrangelo. 2013. Plant nucleotide binding siteleucine-rich repeat (NBS-LRR) genes: Active guardians in host defense responses. International Journal of Molecular Sciences, 14: 7302-7326.

Milus, E. A., K. Kristensen and M. S. Hovmøller. 2009. Evidence for increased aggressiveness in a recent widespread strain of Puccinia striiformisf. sp. tritici causing stripe rust of wheat. Phytopathology, 99: 89-94.

Solh, M., K. Nazari, W. Tadesse and C. Wellings. 2012. The growing threat of stripe rust worldwide. Borlaug
Global Rust Initiative (BGRI) conference, Beijing, China. pp. 1-4.

Steuernagel, B., S. K. Periyannan, I. Hernández-Pinzón, K. Witek, M. N. Rouse, G. Yu, A. Hatta, M. Ayliffe, H. Bariana, J. D. G. Jones, E. S. Lagudah and B. B. H. Wulff. 2016. Rapid cloning of disease-resistance genes in plants using mutagenesis and sequence capture. Nature Biotechnology, 34: 652-655.

Thach, T., S. Ali, C. de Vallavieille-Pope, A. F. Justesen and M. S. Hovmøller. 2016. Worldwide population structure of the wheat rust fungus Puccinia striiform is in the past. Fungal Genetics and Biology, 87: 1-8.

Todorovska, E., N. Christov, S. Slavov, P. Christova and D. Vassilev. 2009. Biotic stress resistance in wheatbreeding and genomic selection implications. Biotechnology \& Biotechnological Equipment, 23: 1417-1426.

Vazquez, M. D., R. Zemetra, C. J. Peterson, X. M. Chen, A. Heesacker and C. C. Mundt. 2015. Multi-location wheat stripe rust QTL analysis: genetic background and epistatic interactions. Theoretical and Applied Genetics, 128: 1307-1318.

Walter, S., S. Ali, E. Kemen, K. Nazari, B. A. Bahri, J. Enjalbert, J. G. Hansen, J. K. M. Brown, T. SicheritzPontén, J. Jones, C. de Vallavieille-Pope, M. S. Hovmøller and A. F. Justesen. 2016. Molecular markers for tracking the origin and worldwide distribution of invasive strains of Puccinia striiformis. Ecology and Evolution, 6: 2790-2804.

Wellings, C. R. 2011. Global status of stripe rust: a review of historical and current threats. Euphytica, 179: 129-141.

Zhai, C., Y. Zhang, N. Yao, F. Lin, Z. Liu, Z. Dong, L. Wang and Q. Pan. 2014. Function and Interaction of the coupled genes responsible for pik-h encoded rice blast resistance. PLoS ONE, 9: e98067. 